\title{
The Mechanism of IOs in Improving Chinese Government's International Public Relations Ability
}

\author{
Lu Meihua \\ School of Public Affairs, Xiamen University, Xiamen, P.R.China, 361005 \\ (E-mail:lmhmel@163.com)
}

\begin{abstract}
In order to analyze the international organizations' mechanisms of action in improving Chinese government's international public relations ability, this article explains why even powerful states channel coercive foreign policy through international organizations bases on events happened in history in which state work through international organizations. Than analyzes the role of international organizations in Chinese government's international public relations in the international environment. Finally, makes a conclusion that IOs play an important role in improving Chinese government's international public relations ability
\end{abstract}

Keywords: International Organizations; foreign policy; public relation

\section{Introduction}

The role international organizations play in the development of a country draw many scholars' attention both domestic and foreign. Chinese scholars usually research the important significance of international organization from a special perspective. Zhu Xufeng(2012) analyzed the international organizations role in policy shift take UNDP participation in China's small credit policy as an example. Zhang Caixia(2011) analyzed the international organizations functions in global health management from a more broad vision. Many foreign scholars, like Alexander Thompson(2006), G.John Ikenberry(2008), Shashi Tharoor(2003) tried their best to explain why states even powerful states channel coercive foreign policy through international organizations.

\section{Mechanism analysis of International organizations in improving governments' public relations ability}

Formal international organizations are prominent though not always successful, participant in many critical episodes in international politics. States are the principal actors in world politics and that they use IOs to create social orderings appropriate to their pursuit of shared goals: producing collective goods, collaborating in prisoner's dilemma settings, solving coordination problems, and the like. We start with the pursuit of efficiency and employ the logic of transaction costs economics and rational choice, using analogies with business firms and medieval trading institutions. Decentralized cooperation theory and, especially, regime theory provide a strong deductive basis for this analysis. States use formal international organizations to manage both their everyday interactions and more dramatic episodes, including international conflicts. States consciously use IOs both to reduce transaction costs in the narrow sense and, more broadly, to create information, ideas, norms, and expectations; to carry out and encourage specific activities; to legitimate or delegitimate particular ideas and practices; and to enhance their capacities and power.

\subsection{The major world powers work through international organizations in improving global voice}

When the United States decided to reverse the Iraqi invasion of Kuwait, it did not act unilaterally. It turned to the United Nations 
(UN) Security Council. When the Security Council sought to learn the extent of chemical, biological, and nuclear arms in Iraq, it did not rely on U.S. forces. It dispatched inspectors from the International Atomic Energy Agency (IAEA). When the international community sought to maintain the suspension of combat in Bosnia, it did not rely only on national efforts. It sent in peacekeeping units under the aegis of the UN and North Atlantic Treaty Organization (NATO). When states liberalized trade in services and strengthened intellectual property protection in the Uruguay Round, they were not content to draft rules. They created the World Trade Organization (WTO) and a highly institutionalized dispute settlement mechanism. As the examples illustrate, moreover, even the most powerful states often act through IOs.

2.2. States work through international organizations in improving international public ability

Examples in addition to those above include the following: Security Council sanctions on Libya, IAEA inspectors in North Korea, UN peacekeepers in the Middle East. Formal organizations help manage many significant areas of interstate relations, from global health policy(the WHO)to European security(OSCE and NATO)to international monetary policy(IMF). What is more, participation in such organizations appears to reduce the likelihood of violent conflict among member states.

Even in the Cold War environment, the United States turned to the United Nations for the Korea intervention and sought cover from regional organizations to take action in Cuba, the Dominican Republic, Panama, and Grenada. Since the Cold War, powerful states have increasingly turned to IOs when using force. The United States has achieved endorsements from the UN Security Council or the North Atlantic Treaty Organization or both, for virtually every intervention since 1990, including those in Iraq, Somalia, Bosnia, Rwanda, Haiti, Zaire, Kosovo, and Afghanistan. The British have behaved similarly and pushed hard for a Security Council resolution authorizing the 2003 Iraq war. Russia and France have also sought UN or regional cover for interventions in the "near abroad" and francophone Africa, respectively. Some middle powers, including Germany, Japan, and Canada, simply will not intervene without an IO mandate.

\section{Cause analysis of international organizations mechanisms in improving government's international relations ability}

Governments that lack resources or expertise often require IO's assistance for material and technical reasons, and weak states rely on international forums to increase their political clout and bargaining power. Powerful states, by contrast, typically do not need IOs to achieve specific objectives. On the contrary, because turning to an international institution complicates policymaking and entails some loss of autonomy, one might expect powerful states to avoid such entanglements. Yet even superpowers sometimes channel coercive actions, including the use of force, through IOs, despite viable alternatives that offer more flexibility and control-namely unilateralism and ad hoc multilateralism.

\subsection{Cause analysis from rational-institutionalism perspective}

Many authors tried their best to explain this phenomenon. In "Why States Act through Formal International Organizations" Kenmeth W.Abbott starting with a rational-institutionalism perspective that sees IOs as enabling states to achieve their ends, examine power and distributive questions and the role of IOs in creating norms and understanding. In his point of view, two characteristics distinguish $10 \mathrm{~s}$ from other international institutions: centralization, a concrete and stable organizational structure and an administrative apparatus managing collective activities; and independence, the authority to act with a degree of autonomy, and often with neutrality, in defined spheres. Centralization and independence are identified as the key properties of formal organizations, and their importance is illustrated with a wide array of examples. Centralization and independence enhance efficiency. Centralization and independence represent different forms of transaction cost economizing. Centralization and independence produce political effects beyond mere efficiency. IOs as community representatives further allow states to create and implement community values and enforce international commitments.

\subsection{Cause analysis from perspective of liberalism}

In "Institutions and Cooperation Sanctions during the Falkland Islands Conflict" Lisa 
L.Martin begins with a brief chronology of the Falklands War and economic sanctions imposed during this episode. His study shows that common interests alone did not explain cooperation. Instead, cooperation resulted from the intense interest of one state, which relied on bargains across issues to consolidate a coalition. An institution played a key role in this process, reducing transaction costs and making the cross-issue linkages credible. Neither neoliberals nor realists have fully anticipated the specific impact of institutions found here. The EEC did not solve a symmetrical collective action problem, as in neoliberal theories, but neither was it irrelevant or epiphenomenal, as most realist theorizing would describe it. This sanctions problem is not an easy test for the proposition that institutions have an impact on state decisions. The Falklands case represents a situation with clear conflicts of interest among states that made the emergence of cooperation problematic.

\section{The mechanism of IOs in Improving Chinese Government's International Public Relations Ability}

The rise of china will undoubtedly be one of the great dramas of the twenty-first century. China's extraordinary economic growth and active diplomacy are already transforming East Asia, and future decades will see even greater increase in Chinese power and influence. The size of its economy has quadrupled since the launch of market reforms in the late 1970s and, by some estimates, will double again over the next decade. It has become one of the world's major manufacturing centers. Just as G.John I. kenberry stated in "The rise of China and the future of the west": China faces an international order that is fundamentally different from those that past rising states confronted. China does not just face the united state; it faces a western-centered system that is open, integrated, and rule-based, with wide and deep political foundations. Today's western order, in short, is hard to overturn and easy to join.

The western order's strong framework of rules and institutions is already starting to facilitate Chinese integration. Obviously, China has pay attention to the role of IOs, in more and more case China choose to take action through IOs. At first, china embraced certain rules and institutions for defensive purposes: protecting its sovereignty and economic interests while seeking to reassure other states of its peaceful intentions by getting involved in regional and global grouping.

China is already a permanent member of the UN Security Council, a legacy of Roosevelt's determination to build the universal body around diverse great-power leadership. This gives china the same authority and advantage of "great-power exceptionalism" as the other permanent members. The existing global trading system is also valuable to china, and increasingly so. China is well aware that no major state can modernize without integrating into the globalized capitalist system; if a country wants to be a world power, it has no choice but to join the world trade organization. The road to global power, in effect, runs through the western order and its multilateral economic institutions. China not only needs continued access to the global capitalist system; it also wants the protections that the system's rules and institutions provide. The WTO's multilateral trade principles and dispute-settlement mechanisms, for example, offer china tools to defend against the threats of discrimination and protectionism that rising economic powers often confront.

The existing international economic institutions also offer opportunities for new powers to rise up through their hierarchies. In the International Monetary Fund and the World Bank, governance is based on economic shares, which growing countries can translate into greater institutional voice. The IMF's existing shareholders, for example, see a bigger role for rising developing countries as necessary to renew the institution and get it through its current crisis of mission. At the IMF's meeting in Singpore in September 2006, they agreed on reforms that will give China, Mexico, South Korea, and Turkey a greater voice.

\section{5 .Conclusions}

Chinese government is well on its way to becoming a global power. China is also well aware that no major state can modernize without integrating, if a country wants to be a world power, it has no choice but to join the world trade organization. In the way of improving Chinese Government's international public relations ability the role of international organizations are unparalleled. 


\section{References}

[1]Alexander Thompson. Coercion Through IOs: The Security Council and the Logic of Information Transmission[J]. International Organization , 2006,60(1):1-291.

[2]Lisa L.Martin. Institutions and Cooperation Sanctions during the Falkland Islands Conflict[J]. International Security, 1992,16(4):143-178.

[3]G.John Ikenberry. The rise of China and the future of the west[J]. Foreign Affairs, 2008,87(1):1-7.

[4]Shashi Tharoor. Why America Still Needs the United Nations[J]. Foreign Affairs, 2003,82(5):67-81.

[5]Kenneth W.Abbot. Why States Act through Formal International Organizations[J]. Journal of Conflict Resolution, 1998,42(1):3-32.

[6]Robert Kelhane.1998.International Institutions: Can Interdependence Work?[J].Foreign Policy, 1998,32(4):379-396.

[7]David A.Lake. Beneath the Commerce of Nations: A Theory of International Economic Structures[J]. International Studies Quarterly, 1984, 28(2):143-170. 